\title{
Hypertension in Postmenopausal Women
}

\author{
Roberta Lima, Marion Wofford, and Jane F. Reckelhoff \\ Department of Physiology and Biophysics, University of Mississippi Medical Center, 2500 North \\ State Street, Jackson, MS 39216-4505, USA \\ Roberta Lima: beta.lima18@gmail.com; Marion Wofford: mwofford@umc.edu; Jane F. Reckelhoff: jreckelhoff@umc.edu
}

\begin{abstract}
Blood pressure is typically lower in premenopausal women than in men. However, after menopause, the prevalence of hypertension in women is higher than it is in men. Hypertension is a major risk factor for cardiovascular disease in women and men. Cardiovascular disease is the leading cause of death in women. Furthermore, there is evidence that blood pressure may not be as well-controlled in women as in men, despite the fact that most women adhere better to their therapeutic regimens and medications than do men, and have their blood pressures measured more frequently than do men. This review describes possible mechanisms by which blood pressure may be increased in postmenopausal women.
\end{abstract}

\section{Keywords}

Menopause; Hypertension; Women; Aging; Obesity; Metabolic syndrome; Sympathetic nervous system; Renin-angiotensin system; Endothelin; Androgens; Estrogen; Depression; Cardiovascular disease; Blood pressure; Hormone replacement therapy

\section{Introduction}

Aging in both men and women is characterized by increases in blood pressure (BP) [1-3, $4 \cdot \bullet, 5-8]$, and the prevalence of hypertension in postmenopausal women is higher than it is in men $[1-3,4 \bullet \cdot]$, with $41 \%$ of postmenopausal women becoming hypertensive [4••]. Worldwide, $25 \%$ of adult women are hypertensive [5], and in the United States, more than $75 \%$ of women older than 60 years of age are hypertensive $[4 \bullet \bullet, 6,7]$. In studies using the National Health and Nutrition Examination Survey (NHANES) IV (1999-2004) dataset, the percentage of individuals with uncontrolled BP was $50.8 \pm 2.1 \%$ in men and $55.9 \pm 1.5 \%$ in women, despite the fact that a greater number of women had their BP measured in the previous 6 months [9]. Furthermore, a study that compared the NHANES III cohort (ending in 1999) with the NHANES IV cohort (ending in 2004) showed that hypertension was less well-controlled in women than men, although the drugs to treat hypertension were similar in men and women [9]. While nondipping of BP at night is associated with increased target organ damage in men and women [10-18], there is evidence that nondipping in women in general is associated with greater target organ damage than in men [10,12], and postmenopausal women are more likely than premenopausal women to exhibit nocturnal nondipping of BP [10]. Thus, although antihypertensive treatments are similar in men and women, and women are more likely to have their BP measured, hypertension appears to be less well-controlled in women. This suggests that women may not be as aggressively treated 
for their hypertension as men and/or that the mechanisms responsible for hypertension in aging women may differ from those in men.

\section{Role of Vasoconstrictors in Hypertension in Women}

One mechanism by which BP may be increased in aging postmenopausal women is activation of the renin-angiotensin system (RAS). Postmenopausal women exhibit increases in plasma renin activity $[14,15]$, suggesting activation of the RAS. In addition, there may be a genetic component of the RAS that contributes to postmenopausal hypertension, as certain renin gene polymorphisms are associated with hypertension in women aged 40 to 70 years, but not in men [16]. In our postmenopausal spontaneously hypertensive rats (SHRs) that exhibit increases in BP with aging to levels that are similar to or higher than those of males, the angiotensin type I (AT1) receptor antagonist losartan reduced but did not normalize BP [17], suggesting that RAS activation was not the only contributor to the postmenopausal BP increases in this model. Thus, the RAS may contribute to hypertension in postmenopausal women but may not be the only mediator.

Chronic infusion of angiotensin II (Ang II) has been shown to stimulate synthesis of preproendothelin [18], another potent vasoconstrictor. When given chronically, endothelin causes increases in sodium reabsorption in the kidney and increases in BP [19, 20]. In postmenopausal women, plasma endothelin levels are increased [21], suggesting that endothelin may play a role in the increased $\mathrm{BP}$ following menopause. The biological activity of endothelin is mediated by two receptors, the $\mathrm{ET}_{\mathrm{A}}$ and $\mathrm{ET}_{\mathrm{B}}$ receptors. The majority of the vasoconstrictor action of endothelin is thought to be mediated via the $\mathrm{ET}_{\mathrm{A}}$ receptors [22]. $\mathrm{ET}_{\mathrm{B}}$ receptors are thought to be coupled to nitric oxide $(\mathrm{NO})$, and $\mathrm{ET}_{\mathrm{B}}$ receptor blockade is associated with increased BP in Ang II-treated rats [23]. Blockade of $\mathrm{ET}_{\mathrm{A}}$ receptors reduces $\mathrm{BP}$ in postcycling female SHRs but has no effect in young females or age-matched males [24]. These data support the contention that endothelin may contribute to the increased BP in postcycling female rats, but again, it is not the only mechanism. Whether there are changes in endothelin receptors in postmenopausal women that may contribute to BP increases has not been studied to our knowledge.

The mechanism by which endothelin increases in postmenopausal women is not clear. Endothelin synthesis can be upregulated by Ang II, as mentioned above [18], and $\mathrm{ET}_{\mathrm{A}}$ receptors have been shown to mediate Ang II hypertension [22, 23, 25]. The role played by estradiol in determining endothelin levels is controversial. While untreated postmenopausal women have been shown to have elevated levels of endothelin, hormone replacement therapy (HRT) with either micronized 17 $\beta$-estradiol and didrogesterone or conjugated equine estrogen and medroxyprogesterone results in further increases in endothelin levels $[26,27]$. Elevated androgen levels that occur with menopause and aging could also increase endothelin levels. Transsexual individuals who receive androgens for masculinization have been shown to have increased plasma endothelin levels [28], although the androgen levels produced by androgen supplements in transsexuals are significantly higher than in postmenopausal women. In contrast, activation of the RAS caused by androgen-mediated increases in angiotensinogen $[29,30]$ could also lead to increases in endothelin, as Ang II stimulates endothelial synthesis [18]. Increased endothelin is also a factor in endothelial dysfunction that occurs with aging. Finally, both endothelin and Ang II can contribute to oxidative stress [31,32], and a consequence of oxidative stress is reduction in NO. Markers of oxidative stress are increased in postmenopausal women [33], and oxidative stress has been shown to increase BP by reducing the bioavailability of the vasodilator, NO [31,32]. However, data from rat studies do not support a role for oxidative stress in contributing to $\mathrm{BP}$ control in females [34]. In human studies, antioxidant therapy (vitamins $\mathrm{E}$ and/or C) has not yielded a reduction in BP $[35,36]$. In addition, in the presence of endothelial 
dysfunction, as occurs with aging and/or chronic diseases, NO levels are reduced, and without an intact NO system, antioxidants are unable to reduce BP [37]. Thus, the role that oxidative stress plays in mediating hypertension in postmenopausal women has not been adequately determined.

\section{Role of Obesity in Postmenopausal Hypertension}

Another mechanism by which BP may be elevated is the presence of obesity [38, 39]. Obesity is one component of the cluster of features known as the metabolic syndrome that also includes insulin resistance, type 2 diabetes, dyslipidemia, and hyperleptinemia, all of which could impact BP $[38,39]$. The prevalence of obesity may be as high as $40 \%$ in postmenopausal women [38]. There are also ethnic differences in the prevalence of obesity in the United States. Recent data indicate that $23.3 \%$ of non-Hispanic white women and $41.9 \%$ of non-Hispanic women are obese [38, 39]. Obesity has been shown to increase after surgical menopause and in women who started HRT within 12 months of amenorrhea [40]. There is also evidence that even if women do not gain additional weight after menopause, there is a redistribution of body fat favoring an increase in abdominal fat rather than subcutaneous fat in the region of the hips [41]. Weight that accumulates in the abdomen is associated with a higher incidence of cardiovascular disease than weight that is accumulated in the lower body [42]. Rossi and colleagues [43] reported that improvement in endothelial dysfunction and inflammation seen in response to antihypertensive medications was attenuated in postmenopausal women aged 47 to 60 years who exhibited symptoms of the metabolic syndrome. Thus, the presence of the metabolic syndrome may not only contribute to hypertension but may affect individual responses to antihypertensive therapies in postmenopausal women.

Whether body weight alone or the combination of obesity and features of the metabolic syndrome, such as insulin resistance, hyperglycemia, and dyslipidemias, contribute to increased BP and increase the risk of cardiovascular and renal disease is controversial. Comparison of data from the Framingham Offspring, Atherosclerosis Risk in Communities, and Cardiovascular Health cohorts over more than 8 years showed that abdominal obesity alone in these cohorts was not significantly associated with increased risk (OR) of cardiovascular disease [42]. However, inclusion of one or two parameters of the metabolic syndrome and diabetes significantly increased the OR of contracting cardiovascular disease in both men and women, suggesting that the presence of metabolic abnormalities and diabetes is more indicative of cardiovascular disease risk than abdominal obesity alone.

\section{Role of Sympathetic Activation in Postmenopausal Hypertension}

Increased body weight, plasma leptin levels, and aging have been shown to cause sympathetic activation $[44,45 \bullet, 46]$. In addition, increased body weight due to increased fat feeding in dogs is associated with BP elevation that can be prevented by renal denervation [47], suggesting that the sympathetic nervous system influences the increase in BP seen with weight gain. Furthermore, obesity is associated with increases in plasma leptin [44, 48], and infusion of leptin increases BP in animals [49]. Blockade of the sympathetic nervous system prevents this hypertensive effect [50], thus implicating leptin in sympathetic activation. Leptin is thought to activate the sympathetic nervous system via activation of melanocortin (MC)4 receptors in pro-opiomelanocortin neurons in the hypothalamus [44, 48]. Blockade of these receptors reduces BP in obese rats [48]. These preclinical observations suggest the possibility that obesity and subsequent increases in leptin can yield increases in BP in preand postmenopausal women via activation of the sympathetic nervous system.

Whether sympathetic activation plays a role in postmenopausal hypertension is not clear, but it is known that sympathetic activity is higher in postmenopausal than in premenopausal 
women [51]. Whether sympathetic activity is increased in postmenopausal women who are not obese is controversial. Czarnecka and colleagues [52] reported that the levels of norepinephrine and leptin were higher in postmenopausal women than age-matched premenopausal women. In contrast, Hogarth and colleagues [51] found that both muscle sympathetic nerve activity (MSNA) and multiunit bursts (b-MSNA) were lower in postmenopausal normotensive and hypertensive women than in age-matched, normotensive, and hypertensive men. Thus, the role of the sympathetic nervous system in hypertension in aging women needs further study.

\section{Role of Estrogen/Androgen Ratios in Hypertension in Women}

Whether the presence of estrogens protects against increases in BP in premenopausal women, and conversely, whether the lack of estrogens contributes to hypertension in postmenopausal women is controversial. For example, Olszanecka and colleagues [53] measured ambulatory BP in normotensive and hypertensive women aged 40 to 60 years and found that BP was similar within normotensive and hypertensive groups independent of menopausal status. Unfortunately, there have been no studies to our knowledge in which ambulatory BP has been measured serially over the perimenopausal transition in order to document any BP change with menopausal transition.

In experimental settings, many in vitro, estradiol has been shown to be cardiovascular protective [54-57, 58•]. However, large clinical trials of the effect of HRT in postmenopausal women have not supported these findings. The results of the Women's Health Initiative (WHI) [59] and HERS I and HERS II [60, 61] trials have not supported a role for HRT in primary or secondary prevention of cardiovascular disease. Similarly, HRT has not been shown to lower BP consistently in postmenopausal women [62-67]. The mode of delivery of HRT (whether oral or transdermal), the dose (whether high or low), and whether estradiol itself or another preparation is used may play a role in the BP effect. For example, conjugated equine estrogen (CEE), a commonly used estrogenic HRT, is derived from the urine of pregnant mares and contains several other steroids, such as androgens. Many studies of the effect of HRT on BP are short term (ie, <1 year). Ichikawa and colleagues [68] found that transdermal hormone therapy for 12 and 24 months reduced diastolic and mean BP in normotensive postmenopausal women. In contrast, Prelevic and colleagues [69] studied healthy postmenopausal women who had been taking HRT for at least 5 years and found that there was either no effect on BP or that BP was in fact higher in some women using HRT. In a new evaluation of WHI, investigators have found that in younger postmenopausal women randomly assigned to the "estrogen only" arm of the study, there was a significant reduction in coronary heart disease after years 7 to 8 [70]. It is likely that BP also may have been favorably affected, although it was not an end point evaluated in this study.

Thus, whether the presence of estrogens protects young women from hypertension or loss of estrogens promotes endothelium-dependent, flow-mediated vasodilation (FMD) hypertension in postmenopausal women is not clear. There is evidence that loss of estrogens at any age contributes to endothelial dysfunction, which is common in individuals with hypertension. For example, Taddei and colleagues [71] reported that FMD in response to acetylcholine, an index of endothelial dysfunction, was attenuated less with aging in premenopausal hypertensive women than in age-matched men, but after menopause, the FMD response was attenuated to the same extent in women and men. Attenuated FMD is prognostic of coronary artery disease risk in postmenopausal women [72]. Women with premature ovarian failure before age 40 years also exhibit reduced brachial FMD compared with age-matched cycling women, but in these women, HRT with CEE and medroxyprogesterone for 6 months reversed the endothelial dysfunction [73]. In contrast, in 
the Women's Angiographic Vitamin and Estradiol (WAVE) trial, HRT had no beneficial effect on FMD in postmenopausal women [74]. The observation that HRT protected against endothelial dysfunction in young, but not in older postmenopausal women, supports the contention that aging may change the response to HRT and thus may independently contribute to increases in BP in postmenopausal women treated with HRT.

Endothelial dysfunction is typically characterized by reductions in NO. Estradiol stimulates NO production acutely by increasing intracellular calcium that activates endothelial NO synthase (eNOS or NOS3) [75]. In addition, estradiol increases NO chronically by upregulating the synthesis of eNOS via a genomic effect. Both acute and chronic effects of estradiol on NO promote vasodilation and thus reductions in BP [76]. Estradiol is a modest antioxidant, as it upregulates superoxide dismutase [77], which removes superoxide, which reduces oxidative stress. Superoxide binds to NO with high affinity and thus renders NO unavailable for vasodilation [31, 32]. An intact NO system is necessary for antioxidants to reduce $\mathrm{BP}$ [34], and in situations of chronic hypertension when endothelial dysfunction is present and NO levels have been reduced for long periods, estradiol may lose the ability to affect BP. Furthermore, an estrogen-mediated increase in superoxide dismutase may result in increased generation of hydrogen peroxide, a powerful oxidant that could offset the beneficial effect of removing superoxide.

Reductions in estradiol with menopause could affect the RAS. Animal studies have shown that estradiol downregulates AT1 receptors and angiotensin-converting enzyme (ACE) [78, 79], thus protecting against activation of the RAS and resultant vasoconstriction. Therefore, reductions in estradiol would tend to activate the RAS. However, in normotensive postmenopausal women, HRT with transdermal 17 $\beta$-estradiol and oral medroxyprogesterone reduced BP but had no effect on levels or expression of RAS components, including plasma renin activity, Ang I or Ang II, aldosterone, and ACE activity [80]. Expression of AT1 receptors was not measured in this study. In contrast, treatment of postmenopausal women with AT1 receptor antagonists improved endothelial function measured by FMD, whereas a calcium channel blocker did not [81], supporting a role for the RAS in contributing to postmenopausal hypertension.

How androgens contribute to hypertension in women is not clear. Young women with polycystic ovary syndrome have elevated levels of plasma androgens with normal plasma estradiol levels, which are associated with increased risk of cardiovascular disease in both the pre- and postmenopausal years [82-84]. Studies in which levels have been measured serially have shown that serum androgens are low immediately following menopause, but by 70 years of age, they are increased to levels found in premenopausal women [85]. The ovary in postmenopausal women is a major source of androgens [86, 87], but increasing evidence supports local production of androgens in nonreproductive tissues, such as the kidney [88]. In addition, serum androgen levels have been shown to increase with increasing body mass index in postmenopausal, but not premenopausal women [89]. In contrast, decreases in androgens are associated with increases in body mass index and obesity in men [90, 91]. Furthermore, elevated serum testosterone is associated with a higher risk of type 2 diabetes in postmenopausal women, but not in age-matched men [92].

\section{Role of Anxiety and Depression in Hypertension in Women}

Anxiety and depression may contribute to hypertension, or conversely, women who are hypertensive may exhibit higher rates of anxiety and depression. Depression and anxiety occur at a significantly higher rate in women than in men [93]. Depression and anxiety also are associated with increased risk of cardiovascular disease. For example, individuals with bipolar disorder have an increased risk of hypertension [94]. Sympathetic activity can be 
increased with anxiety and chronic mental stress, leading to increased BP. This relationship has been demonstrated in individuals with the metabolic syndrome and hypertension [95]. Sustained hypertension was also found to be associated with increased levels of anxiety in a small Spanish cohort [96]. Furthermore, ACE inhibitors used for the treatment of hypertension have been found to reduce the occurrence of depression with anxiety [97]. The mechanisms by which chronic anxiety and depression cause hypertension and may contribute to postmenopausal increases in BP are not clear and should be studied further.

\section{Conclusions}

Hypertension in postmenopausal women likely has multiple etiologies and contributing factors. Women are typically more likely than men to see their health care providers and to be adherent to their medications. Nevertheless, hypertension in this group is less wellcontrolled than in age-matched men, suggesting that different pathophysiologic mechanisms, perhaps multiple concurrent mechanisms that require therapeutic strategies distinct from those that are successful in men, contribute to hypertension in postmenopausal women. Future studies will determine if this is the case or whether women are just not treated as aggressively for their hypertension as are men. Whatever the case, with women living longer than men, the population of older postmenopausal women is in need of improvements in therapeutic approaches to their hypertension in order to improve quality of life and prevent cardiovascular disease outcomes.

\section{Acknowledgments}

The authors acknowledge the support of National Institutes of Health grants RO1s HL66072 and HL69194 and PO1 HL51971 (to Dr. Reckelhoff).

\section{References}

1. Ong KL, Tso AWK, Lam KS, Cheung BM. Gender differences in BP control and cardiovascular risk factors in Americans with diagnosed hypertension. Hypertension. 2008; 51:1142-1148. [PubMed: 18259031]

2. Wiinberg N, Høegholm A, Christensen HR, Bang LE, Mikkelsen KL, Nielsen PE, Svendsen TL, Kampmann JP, Madsen NH, Bentzon MW. 24-h ambulatory BP in 352 normal Danish subjects, related to age and gender. Am J Hypertension. 1995; 8:978-986.

3. Burt VL, Whelton P, Roccella EJ, Brown C, Cutler JA, Higgins M, Horan MJ, Labarthe D. Prevalence of hypertension in the US adult population. results from the Third National Health and Nutrition Examination Survey 1988-1991. Hypertension. 1995; 25:305-313. [PubMed: 7875754]

4. National Center for Health and Statistics Health, United States, 2010, with special feature on death and dying. 2011Hyattsville MDData Tables:67.. This publication contains the most recent national statistics and data on cardiovascular disease and obesity and thus is an excellent resource.

5. Kearney PM, Whelton M, Reynolds K, Muntner P, Whelton PK, He J. Global burden of hypertension; analysis of worldwide data. Lancet. 2005; 365:217-223. [PubMed: 15652604]

6. Taddei S. BP through aging and menopause. Climacteric. 2009; 12(Suppl 1):36-40. [PubMed: 19811239]

7. Pérez-López FR, Chedraui P, Gilbert JJ, Pérez-Roncero G. Cardiovascular risk in menopausal women and prevalent related co-morbid conditions: facing the post-Women's Health Initiative era. Fertil Steril. 2009; 92:1171-1186. [PubMed: 19700149]

8. Sjoberg L, Kaaja R, Tuomilehto J. Epidemiology of postmenopausal hypertension. Int J Clin Pract Suppl. 2004; 139:4-12. [PubMed: 15117107]

9. Kim JK, Alley D, Seeman T, Karlamangla A, Crimmins E. Recent changes in cardiovascular risk factors among women and men. J Women's Health (Larchmont). 2006; 15:734-746. 
10. Routledge FS, McFetridge-Durdle JA, Dean CR. Stress, menopausal status and nocturnal BP dipping patterns among hypertensive women. Can J Cardiol. 2009; 25:e157-e163. [PubMed: 19536383]

11. Stolarz K, Staessen JA, O’Brien ET. Night-time BP: dipping into the future? J Hypertension. 2002; 21:2131-2133.

12. Verdecchia P, Porcellati C, Schillaci G, Borgioni C, Ciucci A, Battistelli M, Guerrieri M, Gatteschi C, Zampi I, Santucci A, Ambulatory BP. An independent predictor of prognosis in essential hypertension. Hypertension. 1994; 24:793-801. [PubMed: 7995639]

13. Ben-Dov IZ, Kark JD, Ben-Ishay D, Mekler J, Ben-Arie L, Bursztyn M. Predictors of all-cause mortality in clinical ambulatory monitoring. Unique aspects of BP during sleep. Hypertension. 2007; 49:235-1241.

14. Schunkert H, Danser AH, Hense HW, Derkx FH, Kurzinger S, Riegger GA. Effects of estrogen replacement therapy on the renin-angiotensin system in postmenopausal women. Circ. 1997; 95:39-45.

15. Fernandez-Vega F, Abellan J, Vegazo O, De Vinuesa SG, Rodriguez JC, Maceira B, de Castro SS, Nicolas RR, Luno J. Angiotensin II type 1 receptor blockade to control BP in postmenopausal women: influence of hormone replacement therapy. Kidney Int. 2002; (Suppl):S36-S41.

16. Mansego ML, Redon J, Marin R, González-Albert V, Martin-Escudero JC, Fabia MJ, Martinez F, Chaves FJ. Renin polymorphisms and haplotypes are associated with BP levels and hypertension risk in postmenopausal women. J Hypertension. 2008; 26:230-237.

17. Yanes LL, Romero DG, Iliescu R, Zhang H, Davis D, Reckelhoff JF. Postmenopausal hypertension: role of the renin-angiotensin system. Hypertension. 2010; 56(3):359-363. [PubMed: 20679182]

18. Alexander BT, Cockrell KL, Rinewalt AN, Herrington JN, Granger JP. Enhanced renal expression of preproendothelin mRNA during chronic angiotensin II hypertension. Am J Physiol Regul Integr Comp Physiol. 2001; 280:R1388-R1392. [PubMed: 11294758]

19. Wilkins FC Jr, Alberola A, Mizelle HL, Opgenorth TJ, Granger JP. Systemic hemodynamics and renal function during long-term pathophysiological increases in circulating endothelin. Am J Physiol. 1995; 268:R375-R381. [PubMed: 7864231]

20. Mortensen LH, Pawloski CM, Kanagy NL, Fink GD. Chronic hypertension produced by infusion of endothelin in rats. Hypertension. 1990; 15:729-733. [PubMed: 2190924]

21. Komatsumoto S, Nara M. Changes in the level of endothelin-1 with aging. Nippon Ronen Igakkai Zasshi. 1995; 32:664-669. [PubMed: 8551691]

22. Ballew JR, Fink GD. Role of ET(A) receptors in experimental Ang II-induced hypertension in rats. Am J Physiol Regul Integr Comp Physiol. 2001; 281:R150-R154. [PubMed: 11404288]

23. Ballew JR, Fink GD. Role of endothelin ETB receptor activation in angiotensin II-induced hypertension: effects of salt intake. Am J Physiol Heart Circ Physiol. 2001; 281:H2218-H2225. [PubMed: 11668086]

24. Yanes LL, Romero DG, Cucchiarelli VE, Fortepiani LA, Gomez-Sanchez CE, Santacruz F, Reckelhoff JF. Role of endothelin in mediating postmenopausal hypertension in a rat model. Am J Physiol Regul Integr Comp Physiol. 2005; 288:R229-R333. [PubMed: 15319224]

25. Sasser JM, Pollock JS, Pollock DM. Renal endothelin in chronic angiotensin II hypertension. Am J Physiol Regul Integr Comp Physiol. 2002; 283:R243-R248. [PubMed: 12069950]

26. de Kraker AT, Kenemans P, Smolders RG, Kroeks MV, van der Mooren MJ. Short-term effects of continuous combined oestrogen-progestogen therapy on several cardiovascular risk markers in healthy postmenopausal women a randomized control trial. Eur J Obstet Gynecol Reprod Biol. 2009; 142:139-144. [PubMed: 19095343]

27. Polderman KH, Stehouwer CD, van Kamp GJ, Dekker GA, Verheugt FW, Gooren LJ. Influence of sex hormones on plasma endothelin levels. Ann Intern Med. 1993; 118:429-432. [PubMed: 8439117]

28. van Kesteren PJ, Kooistra T, Lansink M, van Kamp JG, Asscheman H, Gooren LJ, Emeis JJ, Vischer UM, Stehouwer CD. The effects of sex steroids on plasma levels of marker proteins of endothelial cell functioning. Thromb Haemost. 1998; 79:1029-1033. [PubMed: 9609242] 
29. Chen Y-F, Naftilan AJ, Oparil S. Androgen-dependent angiotensinogen and rennin messenger RNA expression in hypertensive rats. Hypertension. 1992; 19:456-463. [PubMed: 1568764]

30. Ellison KE, Ingelfinger JR, Pivor M, Dzau VJ. Androgen regulation of rat renal angiotensinogen messenger RNA expression. J Clin Invest. 1989; 83:1941-1945. [PubMed: 2723066]

31. Romero JC, Reckelhoff JF. Role of angiotensin and oxidative stress in essential hypertension. Hypertension. 1999; 34:943-949. [PubMed: 10523389]

32. Reckelhoff JF, Romero JC. Role of oxidative stress in angiotensin-induced hypertension. Am J Physiol Regul Integr Comp Physiol. 2003; 284:R893-R912. [PubMed: 12626356]

33. Estaban Castelao J, Gago-Dominguez M. Risk factors for cardiovascular disease in women: relationship to lipid peroxidation and oxidative stress. Med Hypotheses. 2008; 71:39-44. [PubMed: 18308480]

34. Yanes L, Romero D, Iliescu R, Cucchiarelli VE, Fortepiani LA, Santacruz F, Bell W, Zhang H, Reckelhoff JF. Systemic arterial pressure response to two weeks of Tempol therapy in SHR: involvement of NO the RAS oxidative stress. Am J Physiol Regul Integr Comp Physiol. 2005; 288:R229-R233. [PubMed: 15319224]

35. Pechanova O, Simko F. Chronic antioxidant therapy fails to ameliorate hypertension: potential mechanisms behind. J Hypertension Suppl. 2009; 27:S32-S36.

36. McQueen MJ, Lonn E, Gerstein HC, Bosch J, Yusuf S. The HOPE (Heart Outcomes Prevention Evaluation) study and its consequences. Scand J Clin Lab Invest Suppl. 2005; 240:143-156. [PubMed: 16112972]

37. Yanes L, Romero D, Iliescu R, Cucchiarelli VE, Fortepiani LA, Santacruz F, Bell W, Zhang H, Reckelhoff JF. Systemic arterial pressure response to two weeks of Tempol therapy in SHR: involvement of NO, the RAS oxidative stress. Am J Physiol Regul Integr Comp Physiol. 2005; 288:R229-R233. [PubMed: 15319224]

38. Ford ES, Li C, Zhao G, Tsai J. Trends in obesity and abdominal obesity among adults in the United States from 1999 to 2008. Int J Obes (Lond). 2011; 35:736-743. [PubMed: 20820173]

39. Flegal KM, Carroll MD, Ogden CL, Curtin LR. Prevalence and trends in obesity among US adults, 1999-2008. JAMA. 2010; 303:235-241. [PubMed: 20071471]

40. Lobo RA. Metabolic syndrome after menopause and the role of hormones. Maturitas. 2008; 60:1018. [PubMed: 18407440]

41. Ozbey N, Sencer E, Molvalillar S, Orhan Y. Body fat distribution and cardiovascular disease risk factors in pre- and post-menopausal obese women with similar BMI. Endocrinol J. 2002; 49:503509.

42. Wildman RP, McGinn AP, Lin J, Wang D, Muntner P, Cohen HW, Reynolds K, Fonseca V, Sowers MR. Cardiovascular disease risk of abdominal obesity vs metabolic abnormalities. Obesity (Silver Spring). 2011; 19:853-860. [PubMed: 20725064]

43. Rossi R, Nuzzo A, Origliani G, Modena MG. Metabolic syndrome affects cardiovascular risk profile and response to treatment in hypertensive postmenopausal women. Hypertension. 2008; 52:865-872. [PubMed: 18852391]

44. Belin de Chantemèle EJ, Mintz JD, Rainey WE, Stepp DW. Impact of leptin-mediated sympathoactivation on cardiovascular function in obese mice. Hypertension. 2011; 58:271-279. [PubMed: 21690486]

45. Hall JE, da Silva AA, do Carmo JM, Dubinion J, Hamza S, Munusamy S, Smith G, Stec DE. Obesity-induced hypertension: role of sympathetic nervous system, leptin and melanocortins. J. Biol Chem. 2010; 85:17271-17276. [PubMed: 20348094] . This review describes the roles played by leptin and the MC4 receptor in mediating increased sympathetic activity in obesity.

46. Esler MD, Elkelis N, Lambert E, Straznicky N. Neural mechanisms and management of obesityrelated hypertension. Curr Cardiol Rep. 2008; 10:456-463. [PubMed: 18950554]

47. Kassab S, Kato T, Wilkins FC, Chen R, Hall JE, Granger JP. Renal denervation attenuates sodium retention and hypertension associated with obesity. Hypertension. 1995; 25:893-897. [PubMed: 7721450]

48. Haynes WG, Morgan DA, Djalali A, Sivitz WI, Mark AL. Interactions between the melanocortin system and leptin in control of sympathetic nerve traffic. Hypertension. 1999; 33:542-547. [PubMed: 9931162] 
49. Shek EW, Brands MW, Hall JE. Chronic leptin infusion increases arterial pressure. Hypertension. 1998; 31:409-414. [PubMed: 9453337]

50. Hall JE, Hildebrandt DA, Kuo J. Obesity hypertension: role of leptin and sympathetic nervous system. Am J Hypertens. 2001; 14:103S-115S. [PubMed: 11411745]

51. Hogarth AJ, Burns J, Mckintosh AF, Mary DA. Sympathetic nerve hyperactivity of essential hypertension is lower in postmenopausal women than men. J Hum Hypertension. 2008; 22:544549.

52. Czarnecka D, Pośnik-Urbańska A, Kawecka-Jaszcz K, Kolasińska-Kloch W, Wojciechowska W, Fedak D. Indices of autonomic nervous system activity in women with mild hypertension in the perimenopausal period. Kardiol Pol. 2009; 67:243-251. [PubMed: 19378230]

53. Olszanecka A, Pośnik-Urbańska A, Kawecka-Jaszcz K, Czarnecka D, Fedak D. Adipocytokines and BP, lipids and glucose metabolism in hypertensive perimenopausal women. Kardiolo Pol. 2010; 68:753-760.

54. Pelzer T, de Jager T, Muck J, Stimpel M, Neyses L. Oestrogen action on the myocardium in vivo: specific and permissive for angiotensin-converting enzyme inhibition. J Hypertens. 2002; 20:1001-1006. [PubMed: 12011662]

55. Affinito P, Palomba S, Bonifacio M, Fontana D, Izzo R, Trimarco B, Nappi C. Effects of hormone replacement therapy in postmenopausal hypertensive patients. Maturitas. 2001; 40:75-83. [PubMed: 11684376]

56. Dubey RK, Oparil S, Imthurm B, Jackson EK. Sex hormones and hypertension. Cardiovasc Res. 2002; 53:688-708. [PubMed: 11861040]

57. Nickenig G, Bäumer AT, Grohè C, Kahlert S, Strehlow K, Rosenkranz S, Stäblein A, Beckers F, Smits JF, Daemen MJ, Vetter H, Böhm M. Estrogen modulates AT1 receptor gene expression in vitro and in vivo. Circ. 1998; 97:2197-2201.

58. Langrish JP, Mills NL, Bath LE, Warner P, Webb DJ, Kelnar CJ, Critchley HO, Newby DE, Wallace WH. Cardiovascular effects of physiological and standard sex steroid replacement regimens in premature ovarian failure. Hypertension. 2009; 53:805-811. [PubMed: 19332659] . This publication shows that women 18 to 41 years of age who had premature ovarian failure and were treated with HRT did not have the cardiovascular side effects that women in the WHI cohort experienced. These data support the notion that changes in response to estrogens occur with aging.

59. Burry KA. Risks and benefits of estrogen plus progestin in healthy postmenopausal women. Principal results from the Women's Health Initiative randomized controlled trial. Curr Women's Health Rep. 2002; 2:331-332.

60. Herrington DM. The HERS trial results: paradigms lost? Heart and Estrogen/progestin Replacement Study. Ann Int Med. 1999; 131:463-466. [PubMed: 10498564]

61. Grady D, Herrington D, Bittner V, Blumenthal R, Davidson M, Hlatky M, Hsia J, Hulley S, Herd A, Khan S, Newby LK, Waters D, Vittinghoff E, Wenger N. HERS Research Group. Cardiovascular disease outcomes during 6.8 years of hormone therapy: Heart and Estrogen/ progestin Replacement Study follow-up (HERS II). JAMA. 2002; 288:49-57. [PubMed: 12090862]

62. Cacciatore B, Paakkari I, Hasselblatt R, Nieminen MS, Toivonen J, Tikkanen MI, Ylikorkala O. Randomized comparison between orally and transdermally administered hormone replacement therapy regimens of long-term effects on 24-hr ambulatory BP in postmenopausal women. Am J Obstet Gynecol. 2001; 184:904-909. [PubMed: 11303197]

63. Manhem K, Ahlm H, Milson I, Svensson A. Transdermal oestrogen reduces daytime BP in hypertensive women. J Hum Hypertens. 1998; 12:323-327. [PubMed: 9655654]

64. Seely EW, Walsh BW, Gerhard MD, Williams GH. Estradiol with or without progesterone and ambulatory BP in postmenopausal women. Hypertension. 1999; 33:1190-1194. [PubMed: 10334810]

65. Kaya C, Cengiz SD, Cengiz B, Akgun G. Long-term effects of low dose 17beta-estradiol plus dydrogesterone on 24-hr ambulatory BP in healthy postmenopausal women: a 1 year, randomized, prospective study. Gynecol Endocrinol. 2007; 23(Suppl 1):62-67. [PubMed: 17943541] 
66. Mortensen KH, Hansen KW, Erlandsen M, Christiansen JS, Gravholt CH. Ambulatory arterial stiffness index in Turner syndrome: the impact of sex hormone therapy. Horm Res. 2009; 72:184189. [PubMed: 19729951]

67. de Carvalho MN, Nobre F, Mendes MC, Dos Reis RM, Ferriani RA, Silva de Sá MF. Low-dose transdermal hormone therapy does not interfere with the BP of hypertensive menopausal women: a pilot study. Blood Press Monit. 2008; 13:277-283. [PubMed: 18799953]

68. Ichikawa A, Sumino H, Ogawa T, Ichikawa S, Nitta K. Effects of long term transdermal hormone replacement therapy on the renin-angiotensin-aldosterone system, plasma bradykinin levels and BP in normotensive postmenopausal women. Geriatr Gerontol Int. 2008; 8:259-264. [PubMed: 19149837]

69. Prelevic GM, Kwong P, Byrne DJ, Jagroop IA, Ginsburg J, Mikhailidis DP. A cross-sectional study of the effect of hormone replacement therapy on cardiovascular disease risk profile in healthy postmenopausal women. Fertil Steril. 2002; 77:945-951. [PubMed: 12009348]

70. Harman SM, Vittinghoff E, Brinton EA, Budoff MJ, Cedars MI, Lobo RA, Merriam GR, Miller VM, Naftolin F, Pal L, Santoro N, Taylor HS, Black DM. Timing and duration of menopausal hormone treatment may affect cardiovascular outcomes. Am J Med. 2011; 124:199-205. [PubMed: 21396500]

71. Taddei S, Virdis A, Ghiadooni L, Mattei P, Sudano I, Bernini G, Salvetti A. Menopause is associated with endothelial dysfunction in women. Hypertension. 1996; 28:576-582. [PubMed: 8843881]

72. Rossi R, Nuzzo A, Origliani G, Modena MG. Prognostic role of flow-mediated dilation and cardiac risk factors in post-menopausal women. J Am Coll Card. 2008; 51:997-1002.

73. Kalantaridou SN, Naka KK, Papanikolaou E, Kazakos N, Kravariti M, Calis KA, Paraskevaidis EA, Sideris DA, Tsatsoulis A, Chrousos GP, Michalis LK. Impaired endothelial function in young women with premature ovarian failure: normalization with hormone therapy. J Clin Endocrinol Metab. 2004; 89:3907-3913. [PubMed: 15292326]

74. Kelemen M, Vaidya D, Waters DD, Howard BV, Cobb F, Younes N, Tripputti M, Ouyang P. Hormone therapy and antioxidant vitamins do not improve endothelial vasodilator function in postmenopausal women with established coronary artery disease: a substudy of the Women's Angiographic Vitamin and Estrogen (WAVE) trial. Atherosclerosis. 2005; 179:193-200. [PubMed: 15721027]

75. Weiner CP, Lizasoain I, Baylis SA, Knowles RG, Charles IG, Moncada S. Induction of calciumdependent nitric oxide synthases by sex hormones. Proc Natl Acad Sci USA. 1994; 91:5212-5216. [PubMed: 7515189]

76. Wyatt AW, Steinert JR, Mann GE. Modulation of the L-arginine/nitric oxide signaling pathway in vascular endothelial cells. Biochem Soc Symp. 2004; 71:143-156. [PubMed: 15777019]

77. Iñarrea P, Casanova A, Alava MA, Iturralde M, Cadenas E. Melatonin and steroid hormones activate intermembrane $\mathrm{Cu}, \mathrm{Zn}$-superoxide dismutase by means of mitochondrial cytochrome P450. Free Radic Biol Med. 2011; 50:1575. [PubMed: 21397009]

78. Nickenig G, Bäumer AT, Grohè C, Kahlert S, Strehlow K, Rosenkranz S, Stäblein A, Beckers F, Smits JF, Daemen MJ, Vetter H, Böhm M. Estrogen modulates AT1 receptor gene expression in vitro and in vivo. Circ. 1998; 97:2197-2201.

79. Gallagher PE, Li P, Lenhart JR, Chappell MC, Brosnihan KB. Estrogen regulation of angiotensinconverting enzyme mRNA. Hypertension. 1999; 33:323-328. [PubMed: 9931124]

80. Schunkert H, Danser AH, Hense HW, Derkx FH, Kürzinger S, Riegger GA. Effects of estrogen replacement therapy on the renin-angiotensin system in post-menopausal women. Circ. 1997; 95:39-45.

81. Wassmann K, Ghiassi A, Wassmann S, Böhm M, Nickenig G. AT1 Receptor antagonism improves endothelial dysfunction in postmenopausal women. Maturitas. 2006; 53(2):176-183. [PubMed: 15921866]

82. Diamanti-Kandarakis E. Polycystic ovarian syndrome; pathophysiology, molecular aspects and clinical implications. Exp Rev Mol Med. 2008; 10:1-21. 
83. Chen M-J, Yang W-S, Yang J-H, Chen C-L, Ho H-N, Yang Y-S. Relationship between androgen levels and blood pressure in young women with polycystic ovary syndrome. Hypertension. 2007; 49:1442-1447. [PubMed: 17389259]

84. Shaw LJ, Bairey Merz CN, Azziz R, Stanczyk FZ, Sopko G, Braunstein GD, Kelsey SF, Kip KE, Cooper-Dehoff RM, Johnson BD, Vaccarino V, Reis SE, Bittner V, Hodgson TK, Rogers W, Pepine CJ. Postmenopausal women with a history of irregular menses and elevated androgen measurements at high risk for worsening cardiovascular event-free survival: results from NIHNHLBI Sponsored Women's Ischemia Syndrome Evaluation. J Clin Endocrinol Metab. 2008; 93:1276-1284. [PubMed: 18182456]

85. Laughlin GA, Barrett-Connor E, Kritz-Silverstein D, von Mühlen D. Hysterectomy, oophorectomy and endogenous sex hormones levels in older women: the Rancho Bernardo study. J Endocrinol Metab. 2000; 85:645-651.

86. Krug E, Berga SL. Postmenopausal hyperthecosis: function dysregulation of androgenesis in climacteric ovary. Obstet Gynecol. 1999; 99:893-897. [PubMed: 11975949]

87. Bui HN, Struys EA, Martens F, de Ronde W, Thienpont LM, Kenemans P, Verhoeven MO, Jakobs C, Dijstelbloem HM, Blankenstein MA. Serum testosterone levels measured by isotope dilutionliquid chromatography-tandem mass spectrometry in postmenopausal women versus those in women who underwent bilateral oophorectomy. Ann Clin Biochem. 2010; 47:248-252. [PubMed: 20406776]

88. Quinkler M, Bumke-Vogt C, Meyer B, Bähr V, Oelkers W, Diederich S. The human kidney is a progesterone-metabolizing and androgen-producing organ. J Clin Endocrin Metab. 2003; $88: 2803-2809$.

89. Lukanova A, Lundin E, Zeleniuch-Jacquotte A, Muti P, Mure A, Rinaldi S, Dossus L, Micheli A, Arslan A, Lenner P, Shore RE, Krogh V, Koenig KL, Riboli E, Berrino F, Hallmans G, Stattin P, Toniolo P, Kaaks R. Body mass index, circulating levels of sex steroid hormones, IGF-I and IGFbinding protein-3: a cross-sectional study in healthy women. Eur J Endocrinol. 2004; 150:161171. [PubMed: 14763914]

90. Malkin CJ, Pugh PJ, Jones RD, Kapoor D, Channer KS, Jones TH. The effect of testosterone replacement on endogenous inflammatory cytokines and lipid profiles in hypogonadal men. J Clin Endocrinol Metab. 2004; 89:3313-3318. [PubMed: 15240608]

91. Stanworth RD, Jones TH. Testosterone in obesity, metabolic syndrome and type 2 diabetes. Front Horm Res. 2009; 37:74-90. [PubMed: 19011290]

92. Ding EL, Song Y, Malik VS, Liu S. Sex differences of endogenous sex hormones and risk of type II diabetes: a systematic review and meta-analysis. JAMA. 2006; 295:1288-1299. [PubMed: 16537739]

93. Steiner M, Dunn E, Born L. Hormones and mood: from menarche to menopause and beyond. J Affect Disord. 2003; 74:67-83. [PubMed: 12646300]

94. Goldstein BI, Fagiolini A, Houck P, Kupfer DJ. Cardiovascular disease and hypertension among adults with bipolar disorder in the United States. Bipolar Disord. 2009; 11:657-662. [PubMed: 19689508]

95. Lambert E, Dawood T, Straznicky N, Sari C, Schlaich M, Esler M, Lambert G. Association between the sympathetic firing pattern and anxiety level in patients with metabolic syndrome and elevated BP. J Hypertension. 2010; 28:543-550.

96. García-Vera MP, Sanz J, Espinosa R, Fortún M, Magán I. Differences in emotional personality traits and stress between sustained hypertension and normotension. Hypertension Res. 2010; 33:203-208.

97. Braszko JJ, Karwowska-Polecka W, Halicka D, Gard PR. Captopril and enalapril improve cognition and depressed mood in hypertensive patients. J Basic Clin Physiol Pharmacol. 2003; 14:323-343. [PubMed: 15198305] 